\title{
István Jancsó
}

Neste 23 março, faleceu o Prof. Dr. István Jancsó. Historiador de renome, sua obra compreende uma vasta produção relacionada à formação do Estado Nacional brasileiro. Em sua carreira, o professor lecionou em grandes universidades como a USP e a de Nantes (França). Foi diretor do Instituto de Estudos Brasileiros (2002 - 2006) e membro da Comissão Editorial desta revista (2007 - 2008). Atualmente, era professor titular do IEB, editor da revista eletrônica Almanack Braziliense e coordenador do projeto Brasiliana USP. 